\title{
Social Indicators Research: The Little Red Hen 40 Years Later
}

\author{
Alex C. Michalos
}

Accepted: 28 December 2013/Published online: 8 January 2014

(C) Springer Science+Business Media Dordrecht 2013

In August 1978 at the 9th World Congress of Sociology in Uppsala, Sweden, I presented a paper explaining the birth of this journal in 1973 and its early development. That paper was published in Michalos (2005). Among other things, it began with the comment "As I remember it, there's a children's story about a Little Red Hen who repeatedly tried to get others to help with the chores and repeatedly found herself saying 'Very well, I'll do it myself.' That's about how I began SIR".

Since a detailed development story is told in that essay and that book has a robust discussion and republication of the most frequently cited articles in the first 30 years of the journal's life, there is no need to repeat that material here. In this short essay I only want to usher the Little Red Hen out gracefully, express some thanks to others and wish the new Editor the very best of luck.

When I thought about what I should say here, it occurred to me to have a look at Volume One, Number One of the journal to see how I introduced it. To my surprise, I found that I did not write an introduction. That reminded me of a remark I heard on the radio when I was a graduate student in Chicago driving home from my night job in the accounting department of St. Joseph's Hospital. The preacher of an evangelical church said "My daughter is always asking me about rehearsing, but I told her I don't need no rehearsing. Like the angels of the Lord, I just come out singing."

I had a second surprise when I read the material on the back cover of the journal describing what we now call its aim and scope. Much of it, as you will see, I might have written today.

"Social Indicators Research is a quarterly journal intended to serve as a "central clearing house' for research dealing with descriptive, evaluative and prescriptive problems related to the measurement of the quality of life. Since the United Nations

\footnotetext{
A. C. Michalos ( $\square)$

Professor Emeritus, Political Science, University of Northern British Columbia, Prince George, Canada e-mail: michalos@brandonu.ca
} 
took an active interest in the 1950s in measuring 'levels of living', there has been an increasing amount of research in this field. These days, the field of investigation that the United Nations designated by 'levels of living' is more likely to be called the area of social indicators, social reporting, social systems accounting, social bookkeeping or quality-of-life measurement. It is this multi-named and enormously complex area, or more precisely, set of areas to which this journal is devoted.

The quality of one's life is affected by the conditions in which one lives as well as by the activities one engages in and the motives and attitudes that one has toward all of these. The conditions in which one lives are, broadly speaking, physical or psychosocial. The study of the contribution of physical conditions to the quality of human existence takes us into the areas of human (physical) health, population, shelter, transportation and natural environmental quality. The study of the contribution of psycho-social conditions to the quality of human existence takes us into the areas of social customs and morality, mental health, law enforcement, politics, education, religion, the media and arts, science and technology, economics, poverty and welfare. Furthermore, we must be concerned with the interaction of these conditions and human action, motives and attitudes at work, at play and for ordinary nurture or maintenance."

What began as a quarterly journal with 4 issues per year became in 2004 a journal publishing 5 volumes per year with 3 issues per volume. As I write this essay, we have completed not 40 volumes as originally envisioned but 114 volumes and will complete volume 119 by the end of 2014. While there are other journals whose scope overlaps that of SIR, none of them matches our level of production. It is fair to say that SIR is not only the first journal devoted to research on the quality of life but also the most distinguished journal in its field.

The first Editorial Board had 39 members from 19 countries. None of those 39 members is on the current board, which has 68 members from 21 countries.

Roughly 24 years after we launched SIR, I initiated the Social Indicators Research Book Series, a direct descendent of the journal. I have always regretted the fact that the idea for the series came to me so many years later than the journal. We might have contributed much more if we had started earlier. As I write this, there are 52 volumes in this series.

Sixteen years after launching this series, we launched the Quality of Life in Asia Book Series, which currently has three volumes. This time the "we" applies to myself as Editor in Chief and two co-editors, Daniel T.L. Shek and Doh Chull Shin.

As early as 2003 I began having discussions with representatives of Kluwer Academic Publishers to create an encyclopedia of quality of life research that would provide a comprehensive summary of work in the field over the past 50 years and suggest directions for research over the next 10 years or so. In January 2014, Springer will publish my 12 volume Encyclopedia of Quality of Life and Well-Being Research which is the culmination of those discussions.

The basic working assumption for all my journals (seven founded or co-founded) and other editorial projects came to me from a professor when I was a graduate student at the University of Chicago. I don't remember his name, but what he said was that editors should "try to help people get into the conversation". Of course, we have to keep one eye on keeping up our quality standards, but our job as he and I see it is to help bring authors up to those standards so they can have their voices heard and their ideas fairly assessed. That is, the job is not basically that of a gatekeeper but of a helpmate or, to use Socrates's word, a 
midwife. In this respect, editing a scholarly journal or any other kind of scholarly work is very much like teaching. While I am just completing my 40th year of editing this journal, I completed 40 years of university teaching in 2001.

Reflecting on all the excellent scholarly work published in the journal and its direct descendents, I think it is fair to say that the Little Red Hen has had a high level of reproductive success. Nathan Keyfitz, an old friend, fine demographer and sometime Board Member of SIR, wrote that the model of the corpus of science as a building with individual scholars contributing blocks of one sort or another should be replaced by a biological model. From this point of view, he wrote,

\begin{abstract}
"What is old dies and is biodegraded and so provides the raw material for new life. If nothing ever died the natural world would have long ago filled up and evolution would have come to a stop. Knowledge can evolve because with a short delay after one reaches the peak of his or her productivity, each year sees some forgetting, some shrinkage in the references of one's work. The Index of Citations shows in its year to year changes the phenomena of birth and death as they apply to books and articles, and hence to the scholar who wrote them...The teachers' good work is incorporated in the work of others, so losing its identity, just as in biology each creature loses its identity as it is biodegraded into the stuff out of which other creatures grow. Nothing is lost but the atoms are reshuffled, the ideas reassembled, sooner or later without any reference to their original inventor. In short, sooner or later any contribution one of us may make, whether as a teacher or innovative scholar, dies as such and, though biodegraded, is combined with other materials to make the anonymous base from which new knowledge springs...Among living creatures one generation creates the next, and then the created replace their creators; among us one generation teaches the next, and then the taught supplant their teachers" (Keyfitz, 2003, pp.130-131).
\end{abstract}

Usually when I tell Nathan's story, I remark that we all suppose that the work of some of our colleagues is closer to fertilizer than they imagine, but we need not dwell on this. Like so many other ideas he had, I think Nathan had the right idea about scholarly work and the scholarly communities to which we all belong.

Finally, then, I would like to thank many people who have contributed to the success of SIR and its descendents. It is of course impossible to remember and mention everyone by name. Regardless of my omissions, the paragraphs that follow provide evidence that this Little Red Hen was never as alone as I thought.

All of my Board Members, past and present, and many unrecognized peer reviewers have been essential to our work. Ken Land has been on the Board since 1979, has never turned down a manuscript to review and has always provided thoughtful and helpful comments even on papers that appeared very farfetched. If I gave a medal for extraordinary service, he would certainly get it. When I was working on my Citation Classics volume, I noticed that Land's help received a footnote acknowledgement in four of the top ten most frequently published articles.

We would have had no product at all unless hundreds of authors over the years had submitted their manuscripts to us, had them published and cited by other authors. So they deserve our thanks.

The journal was initiated by D. Reidel of Dordrecht, was taken over by Kluwer Academic Publishing and finally by Springer. As one would expect, then, many different people in these organizations had a hand in producing it. I think the production manager with the longest connection to the journal is Jos Walbeek. For 23 years, Jos has been like a steady, reliable lighthouse shining over and guiding all our work through sometimes rough 
seas. People submit manuscripts in all kinds of shapes and diverse, frequently changing technology has been applied to turning them into standard-looking scholarly publications. So it is vitally important for editors to have production managers who are extremely patient and efficient. I have been lucky to have Jos.

Astrid Huizer, Myriam Poort, Esther Otten, Miranda Dijksman and Radha Shankar also have had an immediate impact on the work of the journal. They are listed here by the order of the length of time I worked with them, beginning with Astrid 18 years ago. Their help has been generously given and essential to our success.

I am delighted to have my friend Filomena Maggino take over the editorship. Her expertise, patience, attention to details, entrepreneurial skills and deep interest in quality of life research will certainly contribute to the journal's continued reproductive success. I wish her and all those responsible for the production of Social Indicators Research in the future the very best of luck.

\section{References}

Keyfitz, N. (2003). Nathan Keyfitz on Mr. Somerville and others. In A. C. Michalos (Ed.), The best teacher I ever had (pp. 126-130). London: Althouse Press.

Michalos, A. C. (Ed.). (2005). Citation classics from social indicators research. Dordrecht: Springer. 